\title{
Pengembangan Aplikasi Pengendalian Mutu Uji Terowongan Angin Kecepatan Rendah Indonesia
}

\author{
Ivransa Zuhdi Pane \\ Program Studi Informatika, Universitas Multimedia Nusantara, Tangerang, Indonesia \\ Email: ivransa.zuhdi@lecturer.umn.ac.id
}

\begin{abstract}
Abstrak-Pengendalian mutu dalam layanan uji terowongan angin di Terowongan Angin Kecepatan Rendah Indonesia memegang peran penting untuk menghasilkan hasil uji yang baik, namun masih dilakukan dengan cara manual dan tradisional. Akibatnya, masih terdapat masalah di sisi pelaksanaan dan evaluasi pengendalian mutu dari suatu uji terowongan angin. Pengendalian mutu yang dikelola dengan mendayagunakan teknologi informasi tidak hanya dapat memecahkan masalah tersebut, namun juga mendorong produktivitas dan kinerja personil satuan pengendalian mutu dalam melakukan tugasnya. Pengembangan aplikasi pengendalian mutu sebagai bentuk pemanfaatan teknologi informasi melalui tahapan rekayasa piranti lunak, mulai dari analisis kebutuhan, desain, konstruksi dan uji piranti lunak, diharapkan mampu mewujudkan tata laksana pengendalian mutu kontemporer dan terpadu dengan kegiatan pengelolaan informasi lainnya yang pada gilirannya mendukung pihak manajemen dalam pengambilan keputusan eksekutif.
\end{abstract}

Kata Kunci: Uji Terowongan Angin, Rekayasa Piranti Lunak, Prototyping

Abstract-Quality control in the wind tunnel test service in the Indonesian Low Speed Tunnel plays an important role to produce good test results, but it is still being done in a manual and traditional way. As a result, there are still problems in the implementasion and evaluation of quality control of a wind tunnel test. The quality control which is managed by utilizing information technology can not only solve such problems, but also encourage productivity and performance of quality control unit personnel in carrying out their duties. The development of quality control applications as a form of utilizing information technology through software engineering stages, starting from requirements analysis, design, construction and software testing, is expected to be able to realize contemporary quality control mechanisms and integrated with other information management activities which in turn support the management in executive decision making.

Keywords: Wind Tunnel Test, Software Engineering, Prototyping

\section{PENDAHULUAN}

Layanan uji terowongan angin di Terowongan Angin Kecepatan Rendah Indonesia (TAKRI) merupakan layanan teknis yang diselenggarakan oleh Badan Pengkajian dan Penerepan Teknologi bagi pengguna umum secara terbuka dengan komitmen mutu hasil uji yang baik [1]. Guna mewujudkan komitmen mutu tersebut, pihak manajemen TAKRI secara berkelanjutan berusaha mengembangkan konsep dan mekanisme penerapan pengendalian mutu yang ditargetkan menjadi pedoman implementatif pengendalian mutu di tatanan pelaksanan uji terowongan angin. Namun hingga saat ini, pelaksanaan pengendalian mutu masih dilakukan secara manual dan tradisional. Akibatnya, muncul masalah terutama di sisi pelaksanaan pengendalian mutu suatu uji terowngan angin, dimana data dan informasi yang terakumulasi selama pengukuran tingkat kepatuhan pelaksanaan uji terowongan angin sesuai mekanisme standar pengendalian mutu uji terowongan angin yang berlaku di TAKRI tidak terintegrasi dengan baik karena tidak diadakannya sarana penyimpanan data yang terpusat, seperti server basis data. Dampaknya, evaluasi pelaksanaan pengendalian mutu dari suatu uji terowongan angin pun ikut terkendala karena data dan informasi yang dibutuhkan untuk menghitung tingkat kepatuhan pelaksanaan uji terowongan angin tidak tersedia pada saat dibutuhkan dan harus dikumpulkan secara manual. Sejumlah penelitian telah dilakukan sebelumnya untuk mengembangkan aplikasi-aplikasi berbasis teknologi informasi, namun lebih ditujukan untuk mengelola tugas personil dan pencatatan kegiatan (activity logger) satuan pendalian mutu [2], [3], [4]. Aplikasiaplikasi ini bukan difokuskan untuk mendukung proses pengendalian mutu secara eksplisit. Upaya untuk memecahkan masalah kendali mutu dan mendukung manfaat aplikasi-aplikasi yang telah dikembangkan sebelumnya tersebut adalah pengembangan aplikasi pengendalian mutu uji terowongan angin TAKRI yang mengukur dan mengevaluasi tingkat kepatuhan pelaksanaan uji terowongan angin sesuai mekanisme standar pengendalian mutu uji terowongan angin yang berlaku di TAKRI berbasis teknologi informasi. Dengan adanya aplikasi ini, kegiatan pengendalian mutu, yang selama ini masih dilakukan secara manual dan tradisional, dapat diefisienkan guna mendukung produktivitas dan kinerja personil satuan pengendalian mutu.

Berdasarkan latar belakang tersebut, kegiatan penelitian ini bertujuan mengembangkan aplikasi pengendalian mutu uji terowongan TAKRI melalui tahapan rekayasa piranti lunak yang berlaku secara umum, dimulai dari kegiatan analisis kebutuhan dan desain untuk membentuk kerangka operasional aplikasi, yang selanjutnya akan digunakan dalam proses konstruksi aplikasi fungsional dalam tahap implementasi. Bagian selanjutnya dari makalah ini membahas metode penelitian yang digunakan untuk mengembangkan aplikasi, diikuti dengan pembahasan tentang kegiatan rancang bangun aplikasi beserta hasilnya, dan diakhiri dengan kesimpulan dan saran.

\section{METODE PENELITIAN}


Metode Penelitian yang dipakai dalam kegiatan penelitian ini adalah prototyping, yang merupakan pendekatan rekayasa piranti lunak berciri pembuatan prototipe secara berulang dalam durasi waktu singkat, dimulai dari penggalian kebutuhan piranti lunak hingga piranti lunak target dirampungkan [5]. Seperti ditunjukkan dalam Gambar 1, tahapan siklus prototyping umumnya terdiri dari analisis, desain, konstruksi prototipe dan evaluasi umpan balik terhadap prototipe yang dikonstruksi.

Kegiatan analisis terdiri dari studi literatur, wawancara dengan pengguna potensial dan pengamatan mekanisme kerja dari pengguna potensial (dalam kegiatan penelitian ini adalah personil satuan pengendalian mutu) terkait dengan tata cara pendayagunaan piranti lunak. Hasil dari kegiatan analisis ditindaklanjuti dalam kegiatan perancangan dengan menyusun rancangan basis data, algoritma, dan antarmuka pengguna grafis yang mengendalikan piranti lunak. Penyusunan kode untuk mengkonstruksi prototipe kemudian dilakukan, diikuti dengan uji prototipe untuk memvalidasi operabilitas prototipe. Hasil tahap konstruksi prototipe ini lalu dievaluasi untuk mendapatkan masukan (umpan balik) yang menjadi bahan acuan bagi kegiatan analisis dalam siklus selanjutnya. Siklus seperti ini terus berlanjut sampai produk target tercipta, dimana tiap siklus dilakukan dalam kurun waktu relatif singkat untuk memenuhi kebutuhan piranti lunak tahap demi tahap.

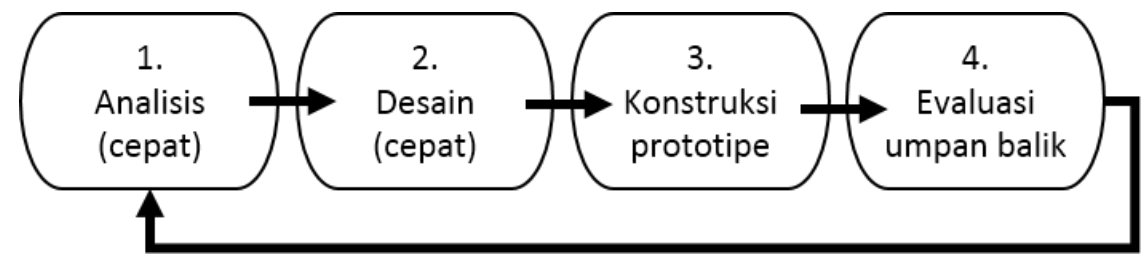

Gambar 1. Konsep prototyping

\section{HASIL DAN PEMBAHASAN}

\subsection{Analisis}

Kegiatan analisis dilaksanakan untuk menggali kebutuhan aplikasi pengendalian mutu uji TAKRI, khususnya melalui observasi tata kerja personil satuan pengendalian mutu. Gambar 2 menunjukkan mekanisme standar pengendalian mutu yang direpresentasikan dengan diagram alir (flow chart). Seperti ditunjukkan dalam Gambar 2, kegiatan pengendalian mutu dimulai dengan perencanaan program pengendalian mutu terhadap suatu uji terowongan angin yang akan dilaksanakan. Kegiatan perencanaan ini diinisiasi oleh satuan pengendalian mutu. Selanjutnya, aspek pengendalian mutu yang akan dievaluasi didefinisikan untuk kemudian diserahkan kepada pihak manajemen TAKRI. Bila pihak manajemen menyetujui seluruh aspek pengendalian mutu yang diusulkan oleh satuan pengendalian mutu, maka aspek pengendalian mutu tersebut ditetapkan dan diuraikan menjadi sejumlah butir penilaian kepatuhan yang memiliki bobot dan rentang nilai tertentu. Bila pihak manajemen tidak menyetujui, maka satuan pengendalian mutu harus mendefisinikan ulang aspek pengendalian. Setelah itu, personil satuan pengendalian mutu ditugaskan untuk melakukan penilaian terhadap kepatuhan pelaksanaan uji terowongan angin ditinjau dari butir-butir penilaian kepatuhan. Hasil penilaian kepatuhan kemudian diolah untuk menentukan tingkat kepatuhan secara keseluruhan dari pelaksanaan uji terowongan angin, yang juga disertai dengan uraian rekomendasi terkait dengan baik buruknya tingkat kepatuhan tersebut, dan pelaporan kepada manajemen TAKRI untuk menjadi bahan pertimbangan dalam pengambilan keputusan.

Berdasarkan mekanisme standar pengendalian mutu yang ditunjukkan dalam Gambar 2 (terutama bagian berwarna abu-abu), maka kebutuhan fungsionalitas aplikasi yang sepatutnya dibentuk adalah :

a. Registrasi program pengendalian mutu uji terowongan angin :

Fungsionalitas untuk melakukan input, edit dan penghapusan data program pengendalian mutu uni terowongan angin, seperti nama program, kategori program, nomor surat keputusan yang terkait, tanggal mulai dan tanggal akhir pelaksanaan program;

b. Registrasi aspek pengendalian mutu uji terowongan angin :

Fungsionalitas untuk melakukan input, edit dan penghapusan data aspek pengedalian mutu uji terowongan angin dari program pengendalian mutu yang diregistrasi sebelumnya di point $a$., seperti aspek personil, aspek dokumentasi, aspek proses dan aspek logistik;

c. Registrasi butir penilaian kepatuhan :

Fungsionalitas untuk melakukan input, edit dan penghapusan data butir penilaian kepatuhan berdasarkan aspek pengendalian mutu yang diregistrasi sebelumnya di point $b$. dalam bentuk kuesioner, seperti kesesuaian kompetensi dan pengalaman personil yang terlibat dalam uji terowongan angin untuk aspek personil, dilaksanakan atau tidaknya suatu kegiatan teknis sesuai prosedur operasi standar selama uji terowongan angin berlangsung untuk aspek proses, serta bobot dan rentang nilainya;

d. Input data hasil penilaian kepatuhan : 
Fungsionalitas untuk menampilkan butir penilaian kepatuhan yang diregistrasi sebelumnya di point $c$. dan input data hasil penilaian kepatuhan, baik dalam bentuk 'Ya' atau 'Tidak', maupun 'Setuju', 'Netral', 'Tidak Setuju', ataupun alternatif lainnya yang sejenis;

e. Olah data hasil penilaian kepatuhan dan input rekomendasi :

Fungsionalitas untuk mengolah data hasil penilaian kepatuhan yang diinput sebelumnya di point $d$. untuk menghitung tingkat kepatuhan pelaksanaan uji terowongan angin dalam rentang 0\% hingga 100\%, dan input rekomendasi yang terkait dengan tingkat kepatuhan tersebut.

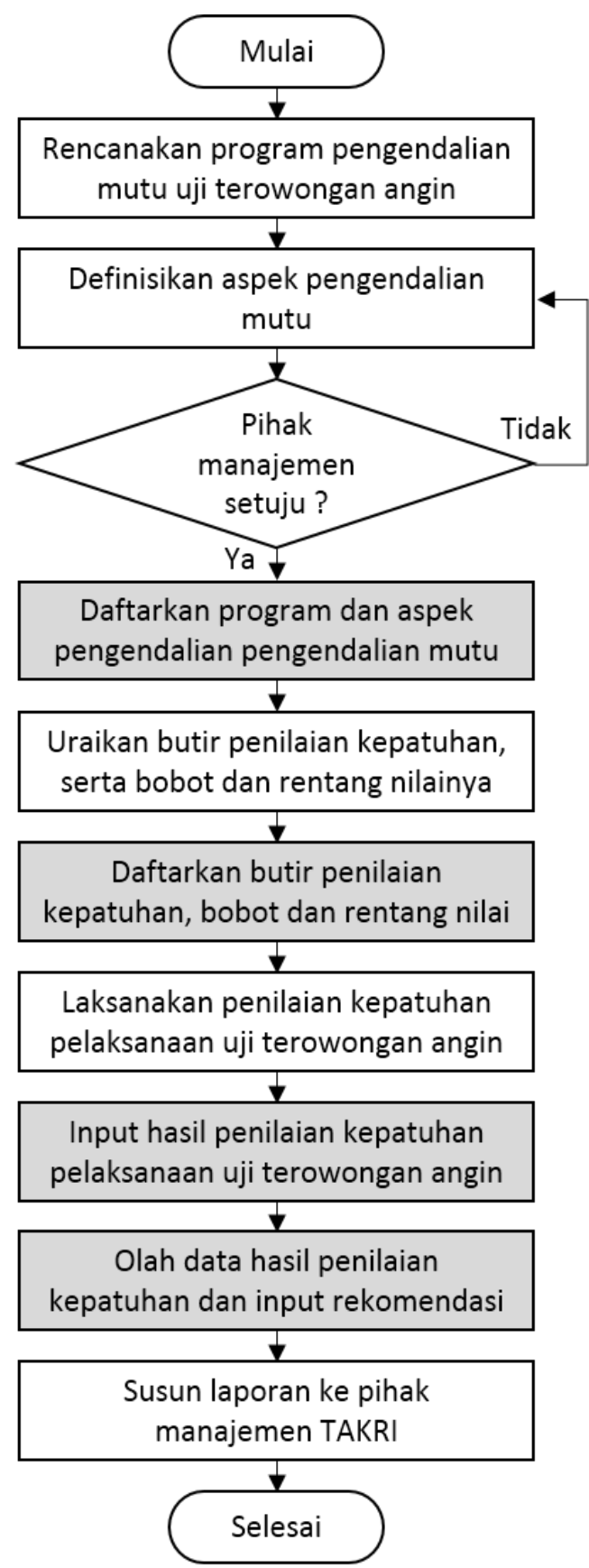

Gambar 2. Mekanisme standar pengendalian mutu

\subsection{Desain}

Kegiatan desain dilaksanakan guna membangun desain antarmuka pengguna grafis, skenario operasionalisasi aplikasi dan basis data. Desain antarmuka dilakukan dengan menggunakan komponen visual yang secara umum digunakan pada platform aplikasi desktop, seperti button, grid, combobox, checkbox dan radiobutton. Gambar 3 hingga Gambar 7 berturut-turut menunjukkan desain antarmuka registrasi program pengendalian mutu uji terowongan angin, desain antarmuka registrasi aspek pengendalian mutu uji terowongan angin, desain antarmuka registrasi butir penilaian kepatuhan, desain antarmuka input data hasil penilaian kepatuhan, serta desain antarmuka olah data hasil penilaian kepatuhan \& input rekomendasi [6]. 


\section{JURNAL MEDIA INFORMATIKA BUDIDARMA}

Volume 4, Nomor 2, April 2020, Page 277-285

ISSN 2614-5278 (media cetak), ISSN 2548-8368 (media online)

Available Online at https://ejurnal.stmik-budidarma.ac.id/index.php/mib

DOI 10.30865/mib.v4i2.2016

Skenario tipikal operasionalisasi aplikasi dapat diusulkan sebagai berikut :

1. Pengguna log in untuk melakukan otentifikasi dengan memasukkan username dan password;

2. Pengguna melakukan registrasi program pengendalian mutu uji terowongan angin;

3. Pengguna melakukan registrasi aspek pengendalian mutu uji terowongan angin dari program yang telah diregistrasi sebelumnya;

4. Pengguna melakukan registrasi butir penilaian kepatuhan dari aspek pengendalian mutu yang telah diregistrasi sebelumnya;

5. Pengguna menginput hasil penilaian kepatuhan yang telah diregistrasi sebelumnya, setelah memantau secara fisik kegiatan pelaksanaan uji terowongan angin yang terkait dengan butir penilaian yang akan diinput;

6. Pengguna mengolah data hasil penilaian kepatuhan yang telah diinput sebelumnya dan menginput uraian rekomendasi berdasarkan hasil pengolahan data tersebut;

7. Apabila telah selesai, pengguna dapat melakukan log out.

Basis data ditunjukkan dalam Gambar 8, yang terdiri dari 4 tabel utama, yaitu tabel Program, tabel Aspek, tabel Butir dan tabel Rekomendasi. Masing-masing tabel mempunyai kode identifikasi unik (ID) dan terdapat relasi antar tabel yang dikaitkan dengan ID ini [7].

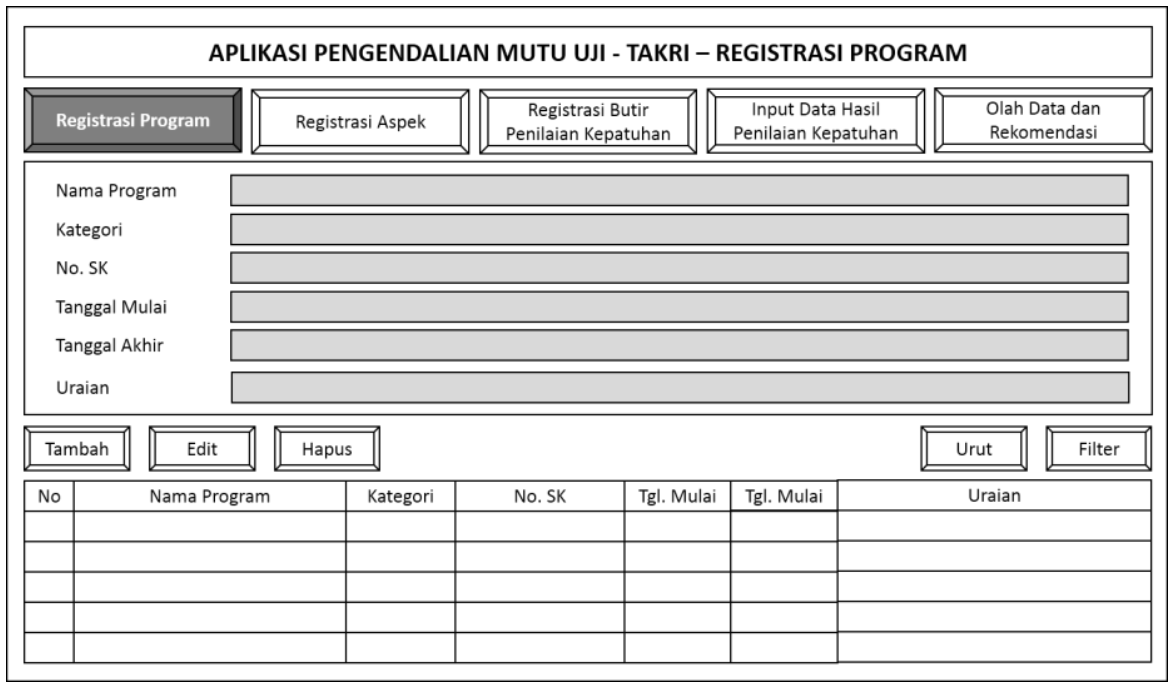

Gambar 3. Desain antarmuka registrasi program pengendalian mutu

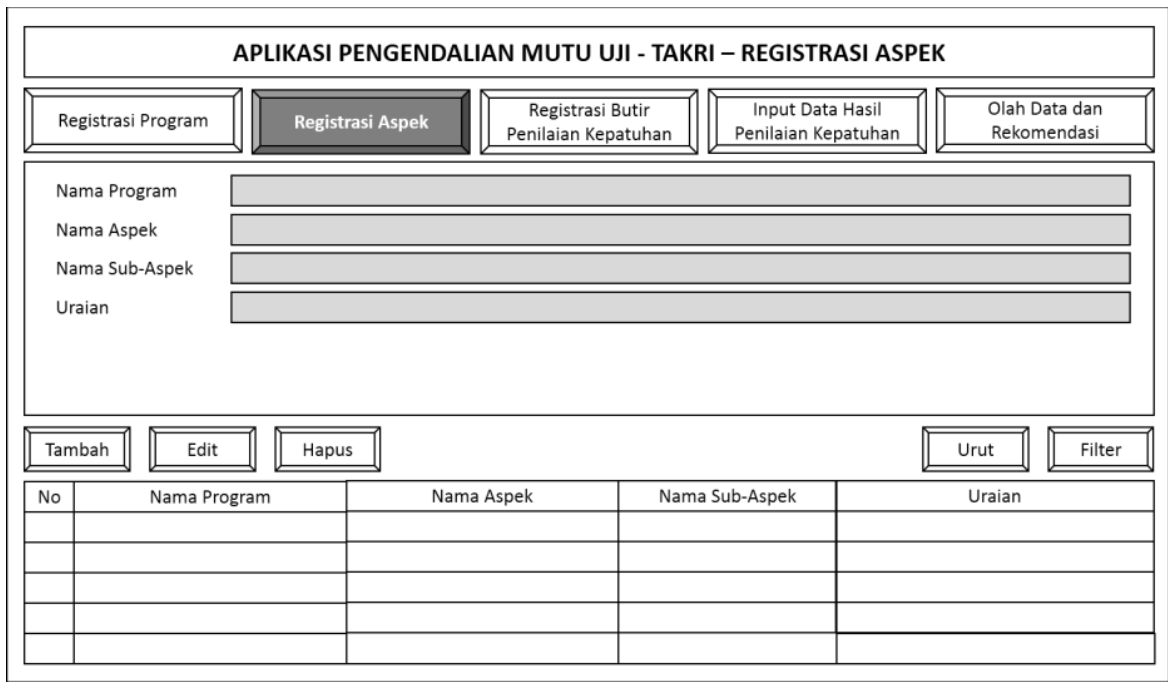

Gambar 4. Desain antarmuka registrasi aspek pengendalian mutu 
JURNAL MEDIA INFORMATIKA BUDIDARMA

Volume 4, Nomor 2, April 2020, Page 277-285

ISSN 2614-5278 (media cetak), ISSN 2548-8368 (media online)

Available Online at https://ejurnal.stmik-budidarma.ac.id/index.php/mib

DOI 10.30865/mib.v4i2.2016

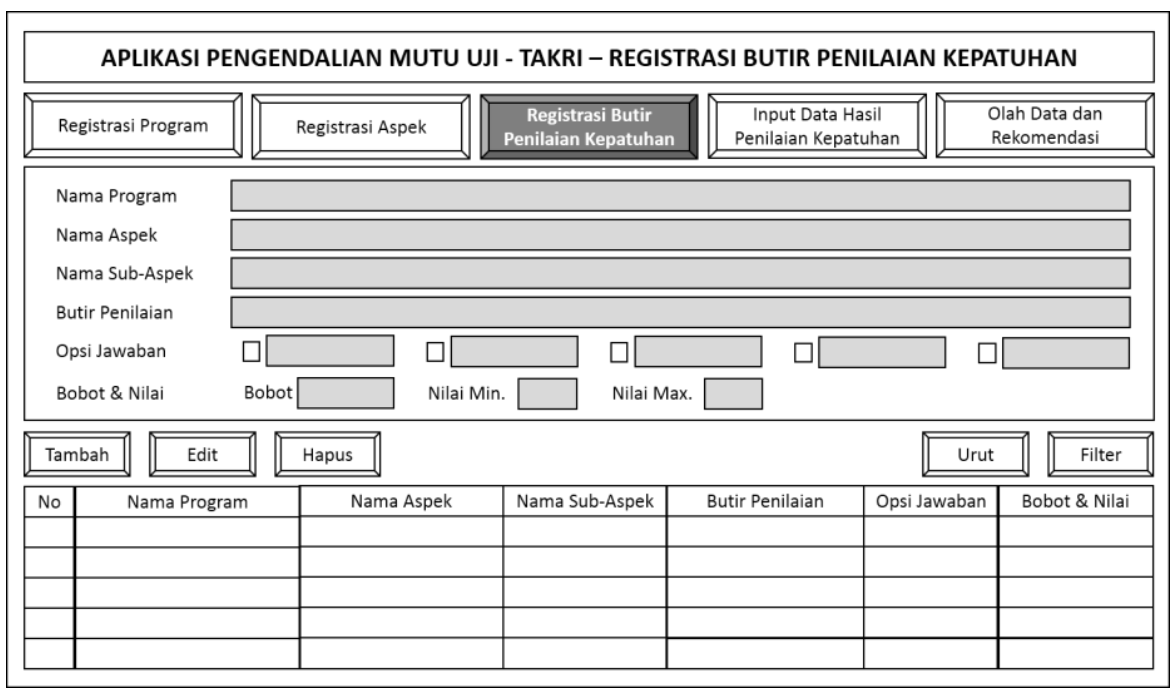

Gambar 5. Desain antarmuka registrasi butir penilaian kepatuhan

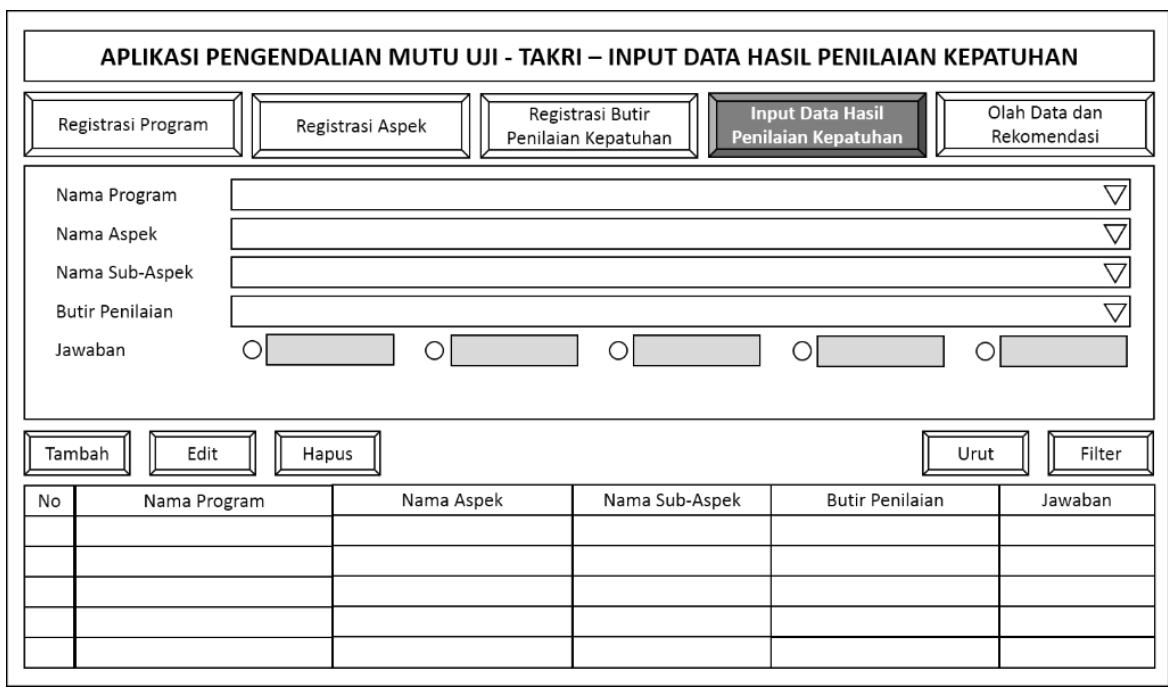

Gambar 6. Desain antarmuka input data hasil penilaian kepatuhan

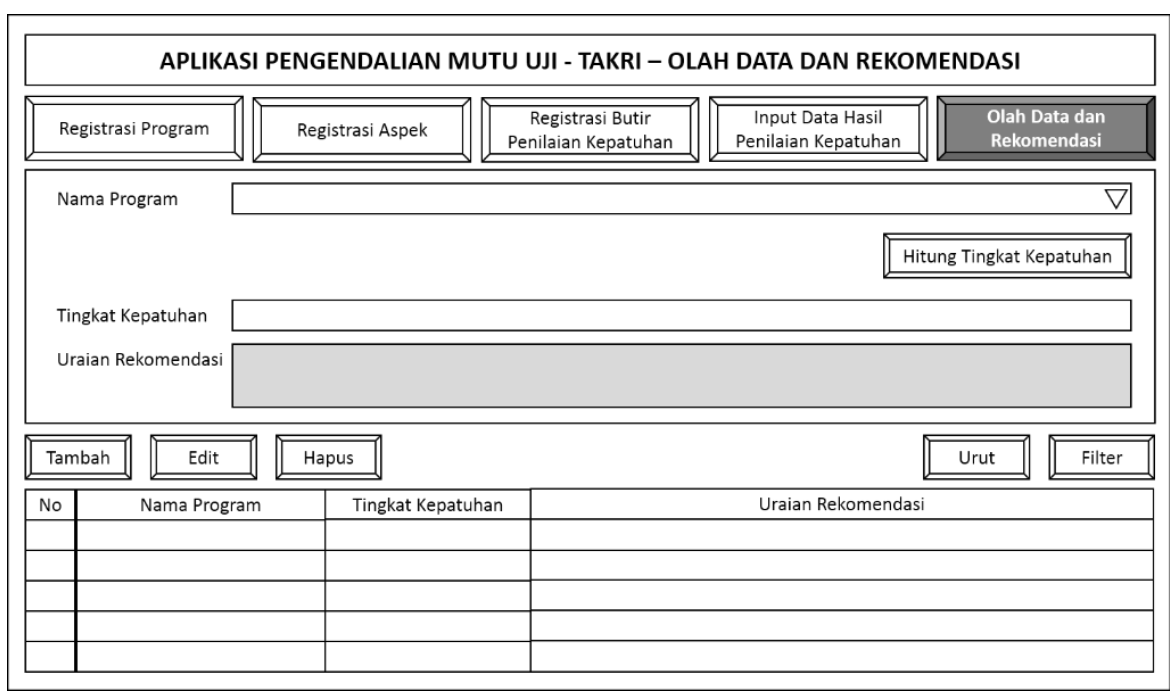

Gambar 7. Desain antarmuka olah data hasil penilaian kepatuhan dan input rekomendasi 


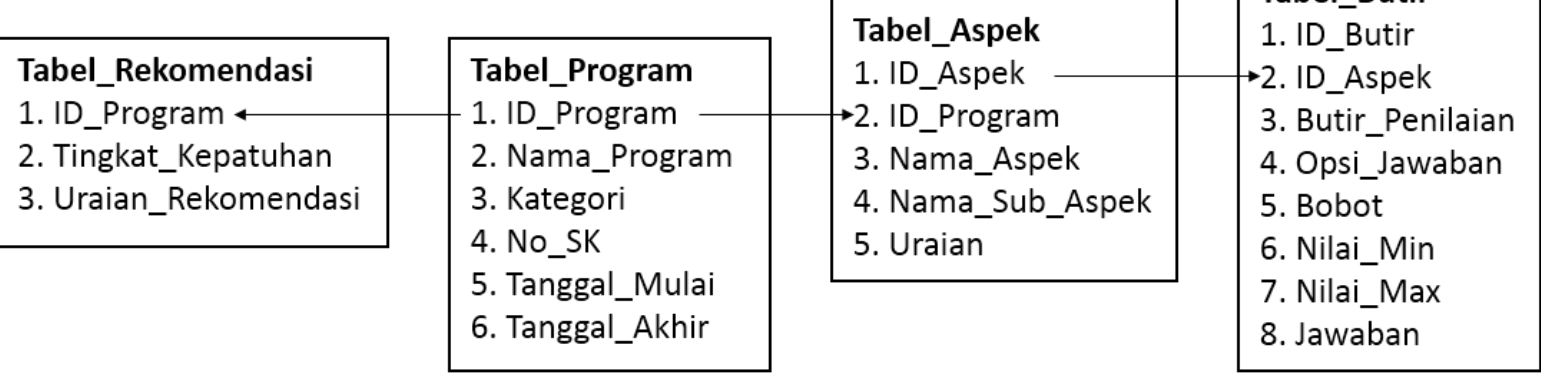

Gambar 8. Tabel basis data

\subsection{Konstruksi Prototipe}

Kegiatan konstruksi prototipe diawali dengan penyusunan kode aplikasi berdasarkan hasil desain dalam bahasa pemrograman Object Pascal [8]. Sementara untuk manajemen basis data, digunakan server basis data MySQL [9]. Pengujian dan validasi hasil kompilasi kode aplikasi kemudian dilaksanakan terhadap sejumlah kasus uji yang dikonfigurasi untuk mampu memastikan operatabilitas aplikasi. Sejumlah kasus uji tipikal yang diterapkan adalah sebagai berikut :

1. Melakukan input sejumlah kombinasi username serta password untuk memvalidasi fungsi otentifikasi pengguna;

2. Memanipulasi kumpulan data, baik yang valid ataupun yang tidak valid, di tiap-tiap menu pendaftaran guna memvalidasi fungsi CRUD (create, read, update and delete) dari masing-masing menu;

3. Melakukan transisi antar menu untuk memvalidasi perilaku setiap menu pada saat diaktifkan.

Koreksi akibat defect yang terjadi pada saat proses pengujian dan validasi berlangsung selanjutnya dilakukan dengan melokalisasi dan menghilangkan sumber kesalahan, yang kemudian dilanjutkan dengan pengujian regresi guna mengkonfirmasi bahwa kesalahan telah teratasi [10].

\subsection{Evaluasi Umpan Balik}

Kegiatan evaluasi umpan balik dimulai dengan menyerahkan prototipe aplikasi yang telah selesai dibangun dalam suatu siklus prototyping kepada beberapa personil satuan pengendali mutu sebagai pengguna potensial untuk diujicobakan. Personil-personil ini kemudian dimintai untuk mengutarakan komentar dan pendapatnya terkait dengan kesesuaian fungsionalitas aplikasi, serta ide inovatif lainnya yang patut untuk dipertimbangkan untuk dikembangkan dalam siklus prototyping berikutnya [11].

\subsection{Hasil Pengembangan}

Hasil pengembangan aplikasi pengendalian mutu uji terowongan angin di TAKRI ditunjukkan dalam Gambar 9 sampai dengan Gambar 13. Antarmuka registrasi program yang ditunjukkan dalam Gambar 9 digunakan untuk meregistrasi program uji terowongan angin yang menjadi target kendali mutu. Selain nama program, pengguna harus memasukkan data atribut program lainnya, seperti kategori, nomor surat keputusan manajemen TAKRI yang mendasari pelaksanaan, tanggal dilaksanakannya dan uraian yang menjelaskan secara ringkas program uji terowongan angin. Setelah data atribut diinput, maka pengguna dapat menyimpannya dengan menekan button Tambah dan sistem akan menampilkan program yang telah teregistrasi di komponen grid yang berada di bagian bawah. Pengguna dapat pula mengubah atau menghapus program dengan masing-masing menekan button Edit dan Delete. Button Urut dan Filter digunakan apabila pengguna ingin menampilkan data program yang telah teregistrasi sesuai kriteria urutan dan filter tertentu. Mekanisme yang didefinisikan dalam kelima button, yaitu Tambah, Edit, Hapus, Urut dan Filter, juga berlaku untuk empat antarmuka lainnya. Antarmuka registrasi apek yang ditunjukkan dalam Gambar 10 digunakan untuk meregistrasi aspek yang akan dinilai dari suatu program uji terowongan angin, berikut dengan sejumlah sub-aspeknya, sesuai dengan preferensi personil kendali mutu yang bertugas dan arahan manajemen TAKRI. Antarmuka registrasi butir penilaian kepatuhan yang ditunjukkan dalam Gambar 11 digunakan untuk meregistrasi pertanyaan yang menjadi butir penilaian dari suatu aspek / sub-aspek dari suatu program uji terowongan angin, berikut dengan opsi jawaban yang mungkin dan mekanisme penilaiannya (dalam hal ini direpresentasikan dengan bobot kepentingan butir penilaian terhadap tingkat kepentingan kendali mutu secara keseluruhan dan distribusi nilai terbesar dan terkecil). Antarmuka input data hasil penilaian kepatuhan yang ditunjukkan dalam Gambar 12 digunakan untuk menilai kepatuhan personil pelaksana uji terowongan angin dalam menjalankan tugasnya di program uji terowongan angin yang menjadi target kendali mutu, sesuai dengan opsi jawaban yang telah didefinisikan sebelumnya di antarmuka registrasi butir penilaian kepatuhan (Gambar 11). Sedangkan antarmuka olah data dan rekomendasi yang ditunjukkan dalam Gambar 13 digunakan untuk menghitung nilai tingkat kepatuhan suatu program uji terowongan angin terhadapa standar mutu yang ditetapkan manajemen TAKRI, serta uraian rekomendasi yang terkait dengan nilai tingkat kepatuhan tersebut. 
JURNAL MEDIA INFORMATIKA BUDIDARMA

Volume 4, Nomor 2, April 2020, Page 277-285

ISSN 2614-5278 (media cetak), ISSN 2548-8368 (media online)

Available Online at https://ejurnal.stmik-budidarma.ac.id/index.php/mib

DOI 10.30865/mib.v4i2.2016

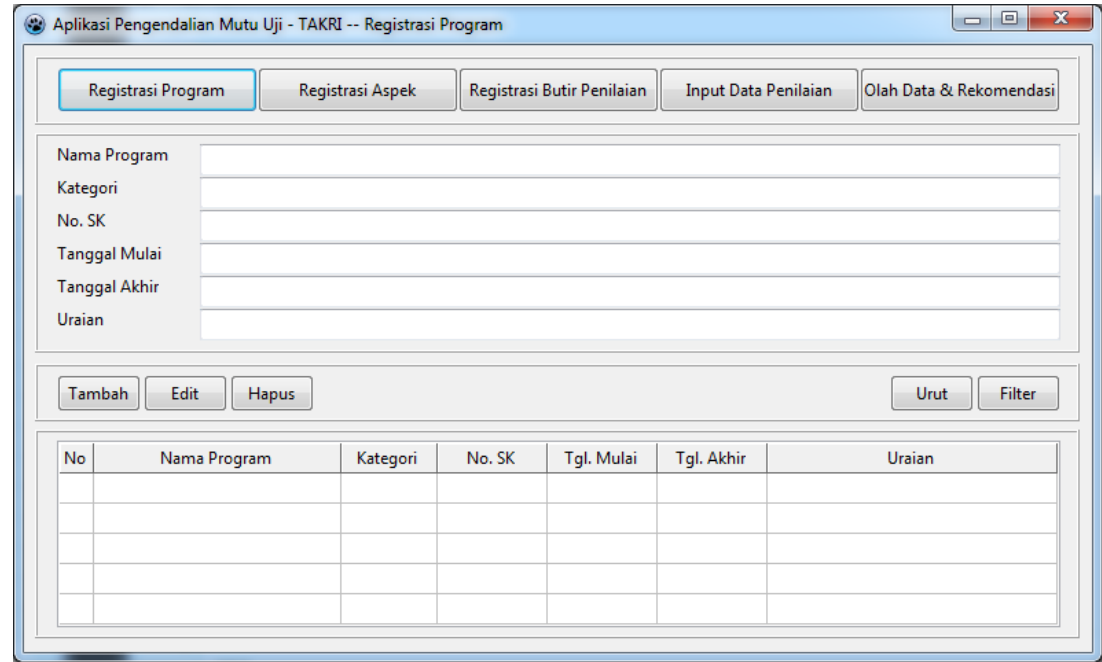

Gambar 9. Antarmuka aktual registrasi program pengendalian mutu

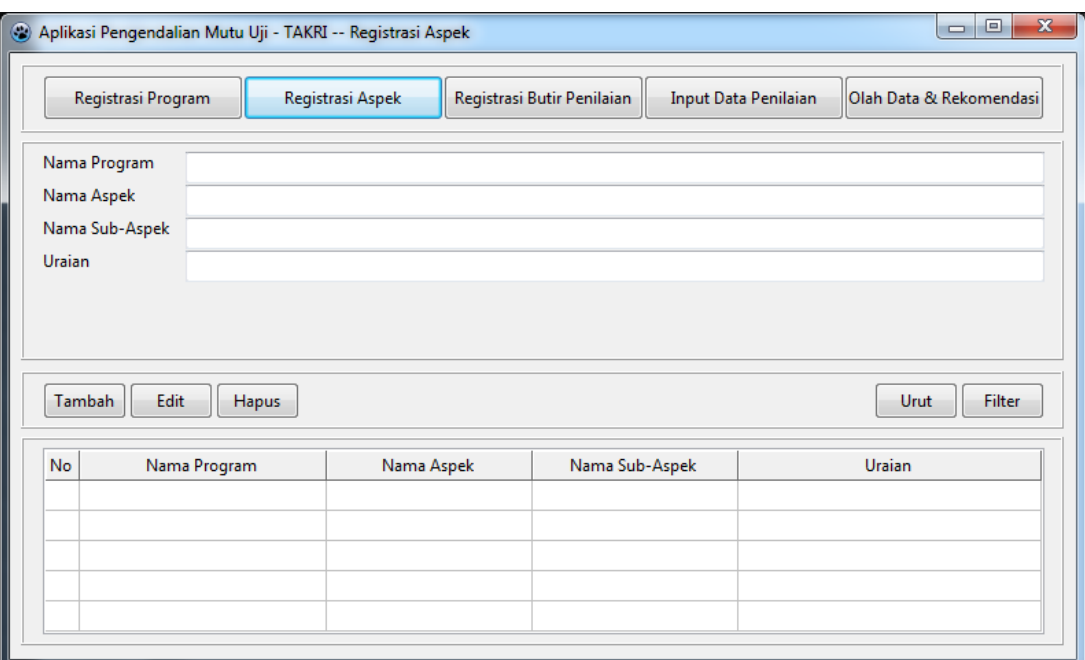

Gambar 10. Antarmuka aktual registrasi aspek pengendalian mutu

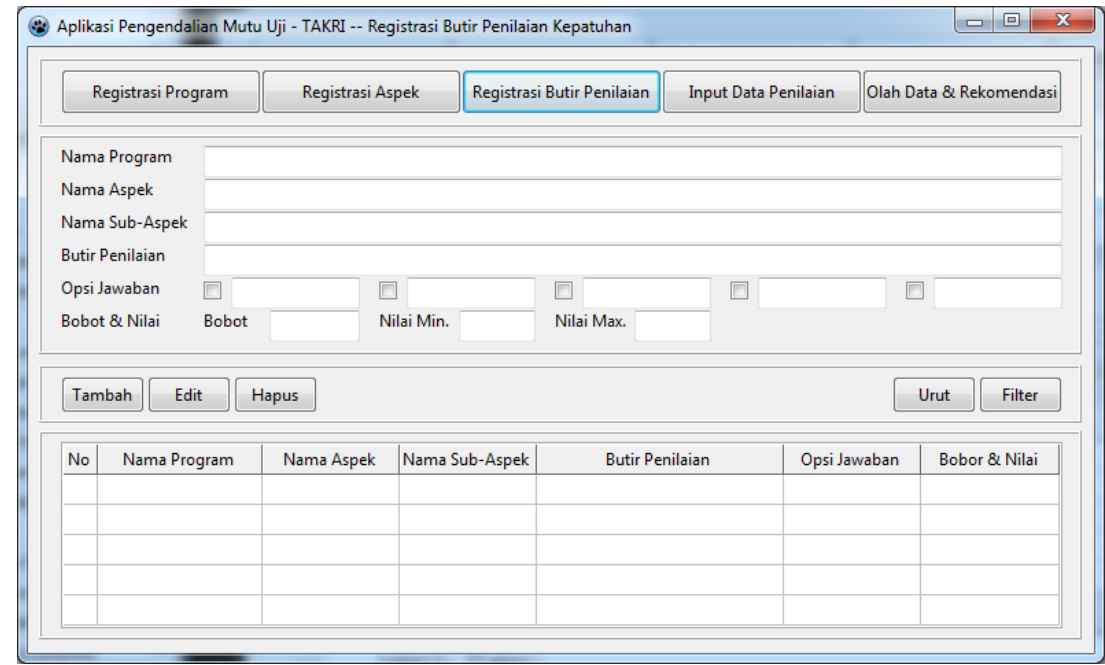

Gambar 11. Antarmuka aktual registrasi butir penilaian kepatuhan 
ISSN 2614-5278 (media cetak), ISSN 2548-8368 (media online)

Available Online at https://ejurnal.stmik-budidarma.ac.id/index.php/mib DOI 10.30865/mib.v4i2.2016

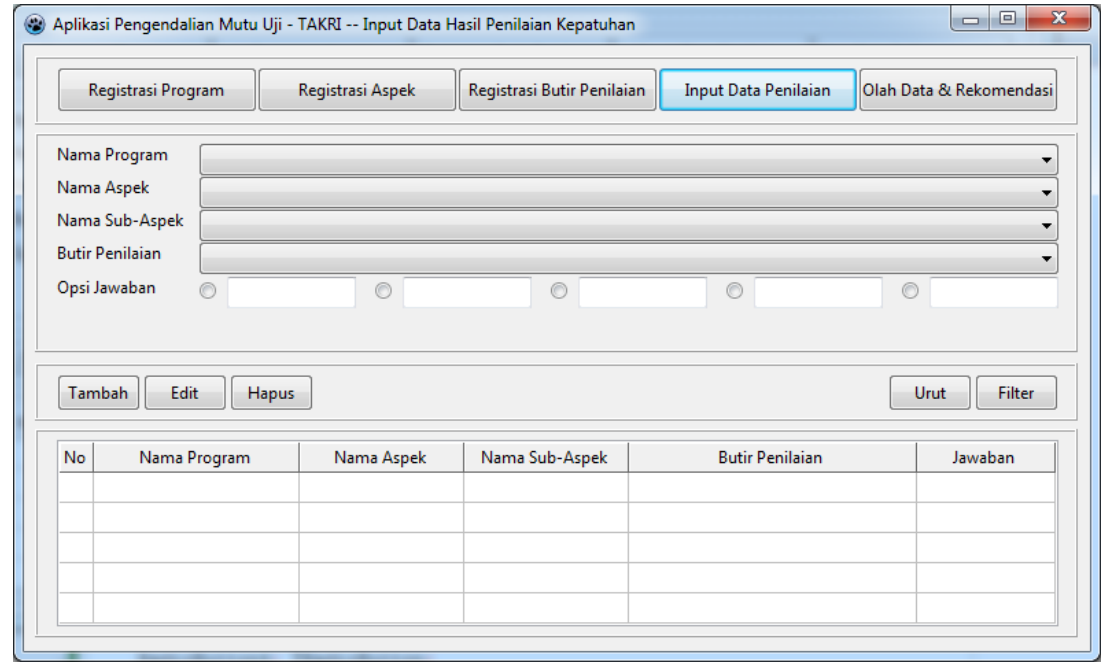

Gambar 12. Antarmuka aktual input data hasil penilaian kepatuhan

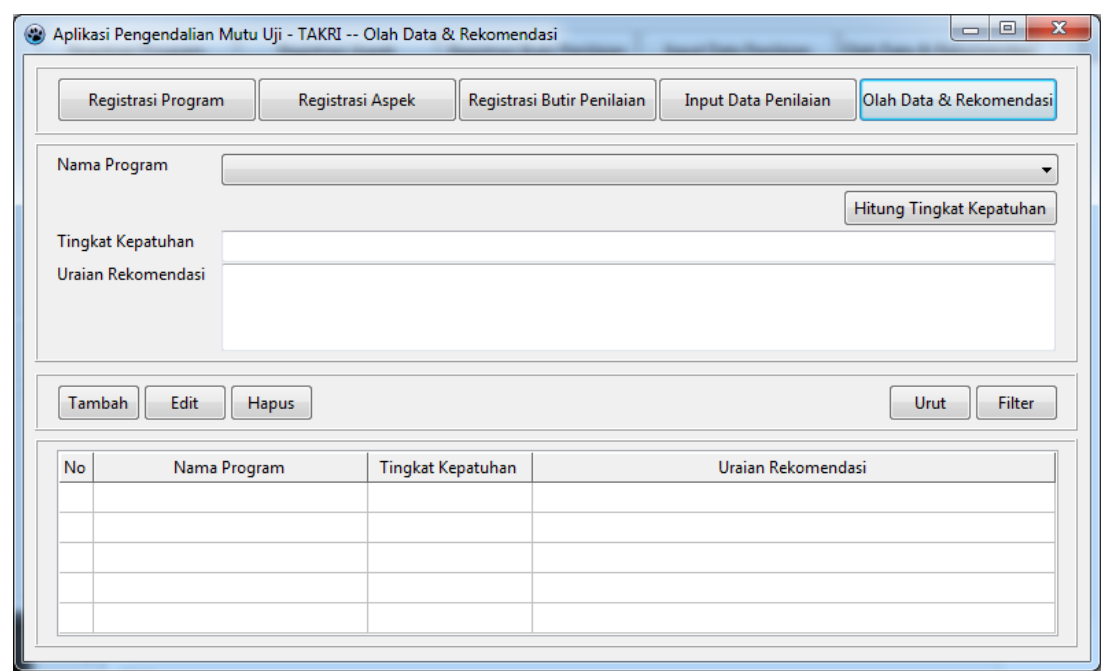

Gambar 13. Antarmuka aktual olah data hasil penilaian kepatuhan dan input rekomendasi

\section{KESIMPULAN}

Rancang bangun aplikasi pengendalian mutu uji terowongan angin di TAKRI telah dilakukan berdasarkan kebutuhan aktual untuk membentuk suatu pedoman implementatif pengendalian mutu di tatanan pelaksanan uji terowongan angin di TAKRI dengan mendayagunakan teknologi informasi untuk mendorong produktivitas dan kinerja sumber daya manusia TAKRI, khususnya personil satuan pengendalian mutu.

Hasil olah data dan rekomendasi yang diproduksi dari aplikasi ini selayaknya dijadikan bahan masukan bagi pihak manajemen TAKRI untuk mengevaluasi mutu uji terowongan angin yang telah dieksekusi dan mengambil keputusan strategis dalam bentuk langkah serta tindakan nyata yang diperlukan guna menciptakan layanan uji terowongan yang lebih baik bagi pihak pengguna layanan dan kondisi kerja yang semakin kondusif bagi para pelaksana uji terowongan angin.

Penyusunan kode program, uji untuk validasi dan verifikasi, serta instalasinya pada platform web dan mobile sangat direkomendasikan untuk dilaksanakan pada siklus prototyping lebih lanjut untuk menciptakan dukungan produktivitas dan kinerja dengan cakupan yang lebih luas, baik bagi pihak manajemen TAKRI maupun personil pengendalian mutu.

\section{UCAPAN TERIMAKASIH}

Penulis mengucapkan terima kasih sebesar-besarnya kepada Universitas Multimedia Nusantara, khususnya Program Studi Informatika, yang mendukung terselenggaranya penelitian ini. Semoga hasil penelitian yang tertuang dalam makalah ini dapat bermanfaat.

\section{REFERENCES}




\section{JURNAL MEDIA INFORMATIKA BUDIDARMA}

Volume 4, Nomor 2, April 2020, Page 277-285

ISSN 2614-5278 (media cetak), ISSN 2548-8368 (media online)

Available Online at https://ejurnal.stmik-budidarma.ac.id/index.php/mib

DOI 10.30865/mib.v4i2.2016

[1] “Indonesian Low Speed Tunnel.” [Online]. Available: http://bbta3.bppt.go.id/fasilitas. [Accessed: 01-Feb-2020].

[2] I. Z. Pane, "Rekayasa Piranti Lunak Pengelola Tugas Personil Organisasi Fungsional Kerekayasaan," J. Ultim., vol. 8, no. 1, 2017, doi: 10.31937/ti.v8i1.503.

[3] I. Z. Pane, "Analisis dan Perancangan Piranti Lunak Pencatat Kegiatan Perekayasa Berbasis Web," in Prosiding Seminar Nasional Multi Disiplin Ilmu 2015, 2015, p. ICT-83.

[4] I. Z. Pane, "Implementasi Piranti Lunak Pencatat Kegiatan Perekayasa Berbasis Web," in Prosiding Seminar Nasional Multi Disiplin Ilmu 2015, 2015, p. ICT-38

[5] R. Pressman and B. Maxim, Software Engineering A Practitioner's Approach, 8th ed. McGraw-Hill, 2014.

[6] B. Shneiderman and C. Plaisant, Designing The User Interface, 5th ed. Pearson, 2009.

[7] T. Connolly and C. Begg, Database Systems. Pearson, 2014.

[8] M. Abiola-Ellison, Getting Started With Lazarus and Free Pascal. Createspace Independent Pub, 2015.

[9] R. Yanto, Manajemen Basis Data Menggunakan MySQL. Deepublish, 2016.

[10] B. Hendradjaya, Konsep Dasar Pengujian Perangkat Lunak. ITB Press, 2017.

[11] A. Stellman and J. Greene, Applied Software Project Management. O’Reilly Media, 2005. 